\title{
The Role of the Entrepreneur in Innovation and in Economic Development
}

\author{
Ari Riswanto \\ SPs Pendidikan Ekonomi \\ Universitas Pendidikan Indonesia \\ Bandung, Indonesia \\ Lecturer STKIP PGRI Sukabumi \\ Indonesia \\ ari_riswanto@student.upi.edu
}

\begin{abstract}
Entrepreneurs have a very important role in the economic development of a country. Development of new business through productive business activities gradually to stimulate increased output and expand the number of transactions of goods and services in an area. In other words, the role of the entrepreneur is the driving wheels of the economy. So the taller the number of entrepreneurs in a country, the taller the level of economic development of the country. Problems in the forefront of economical development in developing countries unresolved is the high unemployment and low growth and economical development of the country. The existence of an entrepreneur can be one of the solutions to solve the problems of economic development. Increasing the number of productive business developed by entrepreneurs means lead to increasing demand for labor. Indirectly, businesses are able to absorb energy and reduce unemployment. The participation of entrepreneurs in economic development itself includes more than just increasing the number of output and income per capita. Innovation entrepreneur on the economic development of a country is greatly important. An understanding of the evolution of the product is still highly poor. It is a process to be followed where innovation is developed and commercialized by entrepreneur's activity, which then stimulate economic growth.
\end{abstract}

Keywords: Entrepreneurs, Innovation Entrepreneurs, Economic Development

\section{INTRODUCTION}

Entrepreneurs have a very important role in the economic development of a country. Development of new business through productive business activities gradually to stimulate increased output and expand the number of transactions of goods and services in an area. Entrepreneurship is considered essential to a dynamic economy. Employers create job opportunities not only for himself but for others as well. entrepreneurial activity can affect the economic performance of a country by bringing new products, methods, and production processes to the market and to increase productivity and greater competition [1]. This proves that the entrepreneur is able to improve the economic conditions of a country, therefore, the growth and economic development one of which is strongly influenced by the presence of entrepreneurs in the country. In other words, the role of the entrepreneur is the driving wheels of the economy.

This study aims to identify the entrepreneur with the innovation has an important role in economic development. Things can be done by the entrepreneurs is maintain power results in creative and innovative thinking so that it is possible to be absorbed by high labor, as one study conducted by David B. Audretsch, Max Keilbach, and Jagannadha Pawan Tamvada, concluded that the academic research conducted in developed countries have been scientifically evaluated the role of entrepreneurship in economic growth, expansion of market coverage, innovation and reduce unemployment. In his research, have consistently shown that areas that have a higher level of entrepreneurs showed a high level of innovation and economic growth is also significant. As a result, most European countries are aware of the potential of entrepreneurship to boost growth and reduce unemployment [2]. So the higher the number of entrepreneurs in a country, the higher the level of economic development of the country.

In the adjustment and development of a new economic activity, entrepreneurship into the life force in the global economy. Today's business environment continues to look for new models of innovative and creative related to the company organization, production and overall market institutions. To prepare for future opportunities and advances in technology, entrepreneurs need to fully understand their business and operating environment in order to develop and utilize the ideas and opportunities that arise [3]. Employers deemed necessary to have expertise in issuing his ideas in the form of something new and innovative, because the innovation itself is the center of the new company, and an understanding of how to integrate knowledge is essential to the innovation of new companies. Acquire knowledge of new technologies and mechanisms to exploit new knowledge is the most important aspect of the absorptive capacity to promote the innovative ability for a young company [4]. Moreover, innovation is a specialized tool 
of entrepreneurs, the means by which they exploit change as an opportunity for a different business or a different service. It is capable of being presented as a discipline, capable of being learned, capable of being put into practice. employers need to seek deliberately to sources of innovation, changes and their symptoms that indicate opportunities for successful innovation [5]. So in other words innovation entrepreneurs will lead to the development of the country the number of entrepreneurs who ultimately by increasing the number of entrepreneurs in the country, the economic development of the country can be increased by itself and it is the primary focus in this study.

\section{THE ENTREPRENEUR INNOVATION IN ECONOMIC DEVELOPMENT}

Entrepreneurship is a process of utilizing the opportunities that exist in the environment or created through innovation in an effort to create value. This often includes the creation and management of a new business venture by an individual or team [6]. There are elements in the concept of entrepreneurship from the economic and social context and behavior. There is a relationship between creativity and innovation in new markets, products, processes and technologies. Entrepreneurship involves competitive action to win the market, take action to capitalize on opportunities and risks involved actors insurer. Economic necessary to study the conditions of a market, to study psychology and motivation of behavior in sociology, management, and organizational behavior to study aspects of entrepreneurial innovation. Conceptually in called entrepreneurs, and innovators since developed into a real innovation always issued.

Besides the other hand, the opportunities will come to depend on factors associated with the change, creativity and innovation, this means that the opportunities that come will come along with the changes made. if so, the approach that should be done is to take an active stance in developing innovative character to develop management processes that are in business activity [7]

In the journal entitled Innovation: A Financial Asset of the Capitalist or an Intellectual Property of the Entrepreneur written by HYSA and Calabrese in 2015 explained that innovation into individual functions of different sociological and reputation as a businessman. It is the entrepreneur who uses her creativity to destroy the old to create the new conditions, to replace the present to create the future and to create a new paradigm for the old paradigm shift towards new things and prosperity, run through the complexity to the temporary certainty. Therefore, if the capitalists have a purely economic order, recognized in the quota of capital provided and expected. Thus, expectations of profit will be owned, but only reward successful innovation to ensure the survival of the company. In other words, the capitalist is done by offering financial capital, expect a financial return rate, and assumption of financial risk. Instead, employers are committed to innovation and change, expect profit as remuneration organizational risk assumed. [8].
While talking entrepreneurship related to economic development, companies with large companies must coexist with each other so that economic activity in a country can run well. For small businesses and entrepreneurship, create a network of closeness between regional actors are different, thus encouraging the exchange of knowledge and information is subtly influence change expertise to support innovation [9]. It is no less important is that the government as policy maker can do a review of the strategy in encouraging entrepreneurship in their respective countries. This is related to long-term economic growth, a strategy that appears associated with entrepreneurial motivation to do with the exploration and evaluation of significant opportunities. if not, then that should be done is the entrepreneurial activity must be motivated by the need to solve short-term problems, but has no effect on long-term economic growth [10]. of the above concept is clear that the employer in this case serves as an innovator in issuing new varieties and increase the amount of production effort, so it can increase the amount of sales of each business unit so that gradually the business activities will grow and will affect the labor market and on eventually will result in the economic development of a country.

In the current era of globalization, the competition took place in the industrial world so rapidly, this company needs innovation more efficient and productive tarhadap all related business activities. Innovation and creativity the main factor that refers to the nature of the products and processes. important for an entrepreneur in changing the way pandan innovation and creativity so that entrepreneurs can take advantage of opportunities that lies in the environment in order to create value [11]. Therefore it is deemed necessary for an entrepreneur to have enough knowledge to develop innovative and creative efforts. Innovation relies on marketing knowledge in various aspects of the industry [12]. We learn to appreciate the human resources at the earliest time can contribute to some extent to preserve the performance of their innovations, thus stimulating their opportunities to build a viable business model and maintain growth in the future and further development [13]. Economic actors build their mental models and how to share mental models lead to certain patterns in behavior; and to investigate how economic actors looking at the economic situation and universal mental construct that came into existence which leads to a bandwagon effect in entrepreneurial action shows a herd of innovation and contribute to the evolution of the industry life cycle [14].

\section{RESEARCH METHODOLOGY}

This study examines the extent to which the role of innovation entrepreneurs in the economic development of a country. This study uses descriptive study using facts from research approach - previous research based journals and reference as qualitatively litelatur. Qualitative research is particularly important in the science of behavior in which the aim is to find the underlying motives of human behavior. Through these studies we can analyze the different factors that 
motivate people to behave in a certain way or that makes people like or dislike certain things. It can be stated, however, that to apply qualitative research. [15].

The flow study conducted by researchers associated with the role of entrepreneurs in economic development begins with determining sample of the number of developed and developing countries, subsequent to the sample the researchers conducted an analysis of the number of entrepreneurs in the country and using studies litelatur-based journals and research previously, researchers conducted a qualitative analysis to discover the extent of the role of innovation entrepreneurs can increase the number of entrepreneurs in the country which in turn will boost economic development in a country. After analysis, the researchers draw conclusions based on the analysis and assessment litelatur so that it can be concluded that if the innovation entrepreneurs can play a role in economic development to be marked with the percentage amount of entrepreneurs in the countryin developing countries and developed countries.

\section{FINDINGS \& DISCUSSIONS}

To have the opportunity to rebuild the industry and the community, the less fortunate countries should commit to a new approach to economic development, as a prerequisite to make smart investments that support a successful strategy, these countries have to develop the infrastructure of analytical required to accurately assess the technology and the economic strength of their urban areas. If not, almost certainly, they will continue to decline as a source of new, enabling technology. [16].

In the world, countries can split into two groups of countries that developed countries and developing countries. Developed countries is the designation for a country whose standard of living is relatively high through high technology and equitable economic. Examples of countries that can be regarded as a developed country, among others, the United States, Hong Kong, the Netherlands, Portugal and many more. While the developing countries is a country with average incomes are low, relatively backward infrastructure, and human development index which is less than the global norm. Example Developing countries: Mexico, India, Malaysia and Indonesia. Indonesia is one of the developing countries. Because the developing countries have a tendency characterized by people who have a per capita income lower than developed countries, usually has a population dense, yet have the economic and social conditions of a prosperous, most people are poor, the thoughts of modern yet infiltrated up to the villages, and technological advances are still very rarely stop to the villages, and the number of unemployed.

Talking about entrepreneurs in Indonesia, the number of new businesses reached $1.65 \%$ of the population as a whole Indonesia. The percentage is far behind Singapore 7\%, Malaysia 5\% and 3\% Thailand. While developed countries like the United States and Japan even has a number of entrepreneurs over 10 per cent of the total population. Although the number of entrepreneurs in Indonesia is still relatively very highly, but a survey conducted by the Global Entrepreneurship Monitor (GEM) in 2013, shows that the desire entrepreneurship Indonesian society is the second highest in ASEAN. [17]

Basically the activities of entrepreneurs will survive or not is determined by the extent of innovation that is raised by the entrepreneurs, whether to make a new effort, replacing the more productive businesses or to start a business with innovation mebu and allow it to compete. while in calculating the innovation of entrepreneurs that affect the economy with rates TEA (Total early-stage Entrepreneurial Activity) in the country while based on data obtained from a survey conducted by a team of global entrepreneurship monitor in 2014 produced that the economy is driven by innovation the highest TEA rates are found in the state of Qatar with the amount of $16.4 \%$ TEA, then Trinidad \& Tobago has a number of TEA of $14.6 \%$, the United States has a TEA amounted to $13.8 \%$, the state Australia has $13.1 \%$ while the number of TEA Canada has a number of state TEA TEA $13.0 \%$. Furthermore, the State of Japan with $3.8 \%$ TEA, and the Italian State with TEA amount of $4.4 \%$, had the lowest share of early stage entrepreneurs among the adult population respectively. Meanwhile, if viewed from the perspective of geography, the highest TEA was found in the African country as much as $37.4 \%$ TEA in the State of Cameroon, $35.5 \%$ in the State of Uganda, $32.8 \%$ in the State Botswana, joined only by Ecuador (from the rest of the world economy) with the amount of TEA was $32.6 \%$. Only in those four economies-third of the adult population are early stage entrepreneurs. As for the economic conditions of Europe has the lowest TEA rate $(7.8 \%$ TEA in EU countries, 6.0\% TEA in non-EU countries). [18]

Indonesia actually has a huge potential for growth and success in the future. According to the World Economic Forum in its Global Competitiveness Report 2014-2015, despite the global competitiveness of Indonesia is still inferior to the three neighboring countries, namely Singapore, Malaysia, and Thailand, but Indonesia was already on Spain, Portugal, Kuwait, Turkey, and Italy. [19]

As for the countries that have the highest number of entrepreneurs are as follows: 1). Uganda: A total of 28.1 percent of the population are entrepreneurs. They take advantage of the freedom that comes after the dictatorship for many years. Many entrepreneurs see their businesses will thrive, let alone the country is just making optical fiber connecting remote villages to the internet. 2). Thailand: There are 16.7 percent of the population being self-employed who work for themselves. Transport is one of the largest sectors such as the tuk-tuk, is a mainstay in the tourism sector. 3). Brazil The number of self-employed reached 13.8 percent, and almost half dominated by female entrepreneurs. 4). Cameroon: A total of 13.7 percent of the population of the country is becoming self-employed and engaged in the service and food. 
5). Vietnam: Approximately 13.3 percent of the population of the country self-employed. Vietnam is famous for prolific stalls and the "barber streets." 6). Angola: A total of 12.4 percent of the jobs in this country are being self-employed. Seller "zungueiros" for men and "zungueiras" for women, make the most of the self-employed. 7). Jamaica: A total of 11.9 percent of the population in the country is self-employed and street vendors. However, the government encourages employers to make a lot of ideas with the advent of technology. 8). Botswana: A total of 11.1 per cent as an entrepreneur by setting up small shops or kiosks. 9). Chile: The country is considered the most stable and prosperous in South America. There are 11 percent of the population prefer to be self-employed [20].

\section{CONCLUSION \& SUGGESTIONS}

Based on the assessment results can be concluded that the innovation entrepreneurs play an important role in the economic development of a country. Innovation entrepreneurs can be viewed with the activities conducted by the entrepreneurs in developing their business, development activities can be done by creating a new product, opening a new business or change a business that can compete era of global competition. The next activity or entrepreneurial activity beginning to show the extent to which the innovation shown by entrepreneurs this will have an impact on increasing the number of entrepreneurs in the country so that the population that there will be more productive. With the increasing number of entrepreneurs who have innovative activities and events that affect the labor market and will reduce the number of unemployed in the country. With the reduction of unemployment and rising standards of living it is likely that the country's economic growth will increase rapidly.

The implication of this research is the need for special attention from various parties, both academics which helps in motivating and gave rise to new entrepreneurs, by maximizing existing curriculum school or college level and by training in fostering new entrepreneurs. In addition, the Government through the relevant ministries must continue to make new breakthroughs in fostering entrepreneurs events and activities in order to focus their activities and to compete with other countries. So that by itself the index numbers TEA (Total early-stage Entrepreneurial Activity) can be improved, which in turn with innovations that emerged from entrepreneurs to develop the economy of a country.

\section{REFERENCES}

A. Kritikos, "Entrepreneurs and their impact on jobs and economic growth," IZA World Labor, no. May, pp. 1-10,
2014.

[2] M. Keilbach, J. P. Tamvada, and D. B. Audretsch, Sustaining Entrepreneurship and Economic Growth: Lessons in Policy and Industry Innovations from Germany and India. 2009.

[3] J. Kickul, Pathways to new business opportunities: innovation and strategies for entrepreneurial classroom. 2006.

[4] G. T. Lumpkin and Jerome A. Katz, Entrepreneurial Strategic Process, vol. 10. 2007.

[5] P. F. Drucker, Innovation and Entrepreneurship: Practice and Principle, vol. 1. 2015.

[6] J. U. Terrence E. Brown, Innovation, Entrepreneurship and Culture, vol. 1.2004.

[7] L. Sołoducho-Pelc, "Searching for Opportunities for Development and Innovations in the Strategic Management Process," Procedia - Soc. Behav. Sci., vol. 210, pp. 77-86, 2015.

[8] X. Hysa and M. Calabrese, "Innovation: A Financial Asset of the Capitalist or an 'Intellectual Property' of the Entrepreneur?," Procedia Econ. Financ., vol. 26, no. 15, pp. 688-694, 2015.

[9] P.-A. Julien, A Theory of Local Entrepreneurship in the Knowledge Economy, vol. 1. 2007.

[10] D. Urbano and S. Aparicio, "Entrepreneurship capital types and economic growth: International evidence," Technol. Forecast. Soc. Change, vol. 102, pp. 34-44, 2016.

[11] E. Kabukcu, "Creativity Process in Innovation Oriented Entrepreneurship: The case of Vakko," Procedia - Soc. Behav. Sci., vol. 195, pp. 1321-1329, 2015.

[12] N. S. Ramli, "Immigrant Entrepreneurs on the World's Successful Global Brands in the Cosmetic Industry," Procedia - Soc. Behav. Sci., vol. 195, no. 0, pp. 113-122, 2015.

[13] J. Maes, L. Sels, and S. De Winne, "Innovation as a corporate entrepreneurial outcome in newly established firms: A human resource-based view," DTEW Res. Rep. 0504, pp. 1-29, 2005.

[14] T. Grebel, Entrepreneurship A New Perspective. Routledge 11 New Fetter Lane, London EC4P 4EE Simultaneously, 2004.

[15] C. Kothari, Research methodology: methods and techniques. 2004.

[16] H. Landstrom, "Economic development through entrepreneurship.," Int. Small Bus. J., vol. 24, no. 5, pp. 540-543, 2006.

[17] J. E. Amorós and N. Bosma, Global Entrepreneurship Report 2013- Global Report. 2014.

[18] S. S. J. E. A. D. Moska, Global Entrepreneurship Monitor 2014 Global Report, vol. 53, no. 9. 2015.

[19] K. Schwab, X. Sala-i-Martín, B. Brende, J. Blanke, B. Bilbao-Osorio, C. Browne, G. Corrigan, R. Crotti, M. D. Hanouz, T. Geiger, T. Gutknecht, C. Ko, and C. Serin, The Global Competitiveness Report. 2014.

[20] Rochimawati, "9 Countries with Highest Number of Employers," viva.co.id, 2015. [Online]. Available: http://bisnis.news.viva.co.id/news/read/642682. 